Константин Казенин, Владимир Козлов

\title{
РЕГИОНАЛЬНЫЕ МЕРЫ ПОДДЕРЖКИ МНОГОДЕТНЫХ СЕМЕЙ В РФ
}

В обзоре делается попытка систематического рассмотрения мер материальной поддержки рождаемости, действующих в РФ на региональном уровне. На фоне большого внимания, уделяемого исследователями результатам федеральной политики по поддержке рождаемости, региональные меры до сих пор не только не изучены в аспекте их результативности, но даже не систематизированы демографами. Между тем, по инициативе федерального центра большинство российских регионов ввели комплекс мер поддержки семей с детьми в первой половине 2010-х гг. В большинстве регионов эти меры действуют до сих пор, при этом различие регионов по конкретному составу мер и по их финансовым масштабам достаточно велико. Наиболее серьезные ресурсы региональные меры поддержки предоставляют семьям после рождения третьего ребенка. Именно поэтому они заслуживают наиболее детального рассмотрения. Многие регионы РФ выплачивают таким семьям региональные материнские капиталы и ежемесячные пособия, а также бесплатно предоставляют земельные участки. Каждая из этих мер используется сегодня как минимум в трех четвертях российских регионов. В настоящем обзоре отдельно рассматривается каждая из этих мер. Регионы сопоставляются по размеру материнских капиталов и пособий, по условиям их предоставления, а также по тому, каким категориям семей выделяются бесплатные земельные участки. Эти данные рассматриваются за разные годы мер поддержки рождаемости. Показано, что, при всей изменчивости экономической ситуации в 2010-е гг, региональная поддержка многодетных семей в этот период в основном расширялась, отказы регионов от каких-либо ранее

Константин Игоревич Казенин-к.филол.н., директор, Центр региональных исследований и урбанистики, ИПЭИ РАНХиГС, Москва, Россия. Электронная почта: kz@ranepa.ru

Владимир Александрович Козлов- к. э.н., доцент, Институт демографии, Национальный исследовательский университет «Высшая школа экономики», Москва, Россия. Электронная почта: vakozlov@hse.ru 
введенных мер были редки. Резюмируются результаты исследований влияния региональных мер на рождаемость. Ставится вопрос о необходимости более глубокого изучения региональной поддержки рождаемости для оценки ее эффективности.

Ключевые слова: рождаемость, регионы, материнский капитал, многодетные семьи

DOI: 10.17323/727-0634-2020-18-2-191-206

Внимание к мерам семейной политики в России связано как с ускоряющейся естественной убылью населения, так и с новыми мерами поддержки рождаемости, предложенными в январе 2020 г. в послании президента. Обзор и оценку эффективности государственных мер поддержки рождаемости, действовавших до 2020 г., проводили регулярно (см. напр., Елизаров 2016; Попова 2016; Андреев, Захаров 2017; Исупова 2018). Введенные в 2020 г. меры, большинство из которых получило законодательное закрепление, включают в себя следующие: (1) продление программы материнского (семейного) капитала до 31 декабря 2026 г. с увеличением на 150 тыс. размера капитала, а также с введением возможности его выплаты после рождения первого ребенка; (2) погашение государством ипотечного кредита при рождении третьего ребенка на сумму 450 тыс. рублей; (3) ежемесячные выплаты на первых и вторых детей до трех лет семьям, чьи доходы не превышают двух прожиточных минимумов на человека; (4) ежемесячные выплаты на детей в возрасте от трёх до семи лет включительно.

При обсуждении новых федеральных мер поддержки рождаемости часто не учитывается то обстоятельство, что объем поддержки семей с детьми на региональном уровне достаточно велик, а формы этой поддержки разнообразны. Однако до сих пор региональные меры не систематизированы исследователями. Цель исследования- восполнить этот пробел, ограничившись при этом мерами поддержки многодетных семей (имеющих трех и более детей), т.к. именно такие семьи получают больше всего ресурсов из региональных бюджетов. Такая систематизация данных о мерах, действующих в различных регионах, видится первым шагом на пути к оценке их эффективности, в том числе на фоне новой федеральной пронаталистской политики. Также исследование региональных мер поддержки рождаемости важно в контексте задач по объяснению разнообразия репродуктивного поведения населения в регионах РФ, которое остается достаточно существенным (Елизаров 2014; Казенин, Ракша 2019).

Идея делегирования на региональный уровень мер по поддержке многодетных семей озвучена президентом РФ Медведевым в Послании Федеральному собранию в 2010 г. Акцент делался на введение в ряде субъектов федерации мер по поддержке многодетных семей с помощью региональных денежных сертификатов (аналогичных федеральному материнскому 
капиталу) и на выделении земельных участков под строительство жилья (или личное подсобное хозяйство). Отметим, что на тот момент в некоторых субъектах РФ такие меры уже действовали. Например, в Ульяновской области на 2010 г. имелись выплаты на третьего ребенка в размере 100 тыс. руб. Выплаты при рождении третьего ребенка действовали в 2010 г. и в Костромской области (300 тыс. руб. семьям, нуждающимся в улучшении жилищных условий, и малоимущим семьям), и в Удмуртии (многодетным семьям на погашение жилищного кредита). В некоторых республиках в составе РФ до инициативы Медведева были предусмотрены выплаты при рождении детей «высоких порядков» (выплата в 250 тыс. руб. при рождении пятого и последующих детей в Кабардино-Балкарии, в 300 тыс. руб. при рождении десятого и последующих детей в Дагестане).

После 2010 г. активность регионов по поддержке многодетных семей значительно возросла. Основными мерами такой поддержки стали: (1) вы-

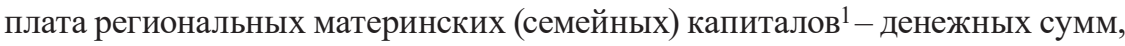
право на распоряжение которыми для приобретения жилья, оплаты образования или некоторых других целей возникает у семей при рождении ребенка определенного порядка (большинство региональных маткапиталов предоставляется при рождении третьего ребенка); (2) выплата ежемесячных пособий; (3) предоставление бесплатных земельных участков.

Необходимо оговорить, что частично региональные меры софинансируются из федерального бюджета. Субъектам РФ, в которых сложилась неблагоприятная демографическая ситуация и величина суммарного коэффициента рождаемости не превышает 2, из федерального бюджета с 2013 г. выделяются ассигнования на софинансирование ежемесячного пособия по уходу за третьим ребенком. Состав регионов, получающих федеральное софинансирование, ежегодно корректируются. Так, в 2015 г. осуществлялось софинансирование денежной выплаты при рождении третьего ребенка в 53 субъектах. В 2019 г. ежемесячная денежная выплата софинансируется из федерального бюджета в 65 регионах. В 2020 г. таких субъектов станет 75 (включая все без исключения регионы Сибирского и Уральского федеральных округов). В федеральном бюджете на 2020 г. на данные цели предусмотрено более 45 млрд рублей. Численность третьих или последующих детей, на которых назначена ежемесячная денежная выплата, составила на конец 2019 г. - 842,8 тыс., это почти 80 \% от числа рожденных в 2013-2019 гг. детей третьей и последующей очередности (см., Минтруд России 2019). Независимо от наличия софинансирования, конкретный состав и объем мер поддержки многодетности определяют сами регионы.

В статье последовательно характеризуется три вышеуказанных меры поддержки многодетных семей по регионам. Поскольку эти меры при-

\footnotetext{
${ }^{1}$ Далее для краткости именуемых региональными материнскими капиталами.
} 
меняются почти десять лет, рассматриваются изменения их характеристик во времени. Источником данных служили нормативные акты субъектов РФ. Кратко описываются также результаты тех немногочисленных на сегодняшний день исследований, в которых оценивается влияние данных мер на рождаемость.

\section{Региональный материнский капитал}

Регионы начали активно вводить материнский капитал как меру поддержки многодетных семей в 2011 г. сразу после президентского послания. Если в 2010 г. региональные материнские капиталы выплачивались только в семи регионах РФ, то в 2011 - уже в 34. Пика популярности эта мера достигла в 2015-2016 гг., когда она действовала в 77 регионах. В 2019 г. региональные маткапиталы выплачивались в 73 субъектах РФ (см. приложение таблицу 1). В большинстве субъектов размер регионального материнского капитала составлял в 2019 г. 100000-150000 руб. (медианное значение100000 руб.). Почти все субъекты неоднократно проводили индексацию регионального маткапитала после начала его выплат.

Помимо размера материнского капитала, регионы различаются по тому, при рождении какого ребенка он предоставляется. Как уже было отмечено, в большинстве регионов он выплачивается при рождении третьего ребенка. В таблице 1 в скобках при регионе указывается порядок рождения ребенка, на которого выплачивается маткапитал, если этот ребенок- не третий. Крайне немногочисленны регионы, выплачивающие маткапитал только при рождении второго ребенка, то есть одновременно с федеральным маткапиталом (в 2019 г. таковыми были Курганская и Ленинградская области). В 2019 г. 11 регионов, выплачивали региональный маткапитал и при рождении второго, и при рождении третьего ребенка. За исключением Ульяновской области, это были регионы Дальнего Востока и Восточной Сибири. В Амурской области, Еврейской автономной области, Забайкальском крае и Бурятии сумма регионального маткапитала при рождении второго ребенка была выше, чем при рождении третьего ребенка; в Камчатском, Приморском и Хабаровском краях, в Якутии и Чукотском АО соотношение было обратным, а в Магаданской области суммы, выделяемые при рождении второго и третьего детей, были в 2019 г. идентичны. Редкую для регионов РФ «прогрессирующую» систему маткапиталов имел в 2019 г. Камчатский край, выплачивающий при рождении второго ребенка 135908 р., третьего143643 р., четвертого- 216068 р. и пятого- 287285 р. Отметим, что большинство перечисленных регионов Сибири и Дальнего Востока начали выплачивать маткапитал при рождении второго ребенка только в 2019 г., ранее предусматривая его только для третьего ребенка.

В целом по стране еще в 2016 г. региональный маткапитал при рождении второго ребенка был предусмотрен только в Курганской и Ульяновской 
областях. Можно предположить, что последующий переход части регионов к поддержке рождаемости вторых детей мыслился как одна из мер противодействия начавшемуся снижению рождаемости. На востоке страны, где эта мера применяется наиболее широко, она, возможно, видится региональным властям и как способ сопротивления общей депопуляции этой части РФ.

При рождении четвертого, но не третьего ребенка выплачивается региональный капитал в Карачаево-Черкессии (с 2012 г., сумма на 2019 г.105500 р.), в Марий Эл (с 2011 по 2019 гг. возрос с 50000 до 58379 р.), в Республике Алтай (выплачивается с 2011 г. в неизменном размере 50000 р.). В ряде регионов существует выплата материнского капитала на детей более высоких очередностей рождения. Например, в Ингушетии небольшие единовременные выплаты назначаются начиная с восьмого ребенка (такая практика существовала ещё до начала 2010-х гг. и изменений с тех пор не претерпела); в Башкортостане, где рождаемость заметно ниже, чем в Ингушетии, маткапитал с 2015 г. выплачивается также при рождении восьмого ребенка и составляет 600000 р. (начали выплачивать с 2015 г.). При рождении пятого ребенка выплачивается региональный маткапитал в Кабардино-Балкарии, Дагестане и Тыве.

Помимо размеров маткапиталов и порядков рождения, при которых они предоставляются, регионы различаются по тому, на что семьи могут использовать маткапитал. Общая тенденция состоит в том, что возможности его применения у́же, чем у федерального маткапитала. В 2019 г. лишь 15 регионов разрешали использовать региональные маткапиталы всеми теми же способами, которыми может быть использован федеральный маткапитал; в 2016 г. число таких регионов составляло 14. В 2019 г. ряд регионов допускал использование маткапитала только на строительство, приобретение или ремонт жилья (Амурская, Белгородская, Костромская области, КабардиноБалкария). Некоторые регионы разрешали использование регионального маткапитала на приобретение автомобиля (Камчатский край, Ленинградская, Мурманская, Новосибирская, Орловская, Ростовская, Сахалинская, Тверская, Тульская области, НАО). В ряде регионов законодательство весьма детально определяет состав бытовых нужд, для которых может быть использован маткапитал, включая, например, подключение к электрическим и газовым сетям (Рязанская область), санаторно-курортное лечение ребенка (Якутия), приобретение сельхозтехники (Новосибирская область), приобретение мебели (Мурманская область). В целом это же «меню» использования региональных маткапиталов существовало с момента их введения в 2011 г.

Наконец, регионы отличаются по тому, каким категориям семей выплачивается региональный маткапитал. Большинство регионов не вводит в этом отношении никаких ограничений (в 2019 г. из 73 регионов, выплачивающих маткапитал, в 57 регионах он выплачивался всем семьям при рождении соответствующего ребенка, в 2016 г. - в 64 из 77, в 2013 г.- в 63 из 73). В малом числе регионов он выплачивается только семьям, в которых 
доход на одного члена семьи ниже определенного уровня (например, в 2019 г. в Волгоградской области и Калмыкии- только семьям с доходами ниже полутора прожиточных минимумов, в Ростовской, Челябинской областях, Марий Эл и Чувашии - только семьям с доходами ниже прожиточного минимума на одного человека). В редких случаях регионы устанавливают разные размеры маткапитала для разных категорий семей. Например, в Хакасии в 2019 г. семьи, проживающие в малых селах, при рождении третьего ребенка получали 200000 р., а все прочие семьи- 100000 p.

В большинстве регионов, в которых по состоянию на 2019 г. региональный маткапитал не предусмотрен, он выплачивался ранее. К таким регионам относятся: Астраханская область (выплата при рождении третьего ребенка в размере 58764 р., которую можно тратить на любые цели, существовала до 2017 г. включительно), Московская область (выплаты маткапитала в размере 100000 р. производились с 2011 по 2016 гг. при рождении второго ребенка), Новгородская область (с 2012 по 2018 гг. выплачивалось 200000 р. при рождении третьего ребенка, их можно было использовать не только на жилье, но и на коммунальные платежи, оплату общежития при получении родителями образования), Омская область (с 2011 по 2018 гг. выплата 100000 p. с ежегодной индексацией при рождении третьего ребенка, с возможностью потратить в том числе на газификацию), Смоленская область (выплаты материнского капитала при рождении третьего ребенка начались еще до президентского послания 2010 г., в 2015 г. размер маткапитала достиг 163300р., с 2017 г. выплаты отменены), Пермский край (с 2012 по 2015 гг. выплачивался маткапитал при рождении третьего ребенка), Республика Северная Осетия - Алания (с 2012 по 2018 гг. выплата 50000р. при рождении третьего ребенка, которые можно было потратить в том числе на подготовку ребенка к школе). Лишь четыре региона ни разу не вводили выплат маткапитала после 2010 г.- Татарстан, Чечня, Пензенская область и Ставропольский край (в последнем начало выплат неоднократно анонсировалось, но переносилось на будущее).

Оценка влияния региональных материнских капиталов на рождаемость в первые годы их выплат в (Архангельский, Джанаева 2014) свидетельствует о наличии на 2012 г. прямой положительной связи между величиной регионального материнского капитала и приростом в том же году по регионам суммарного коэффициента рождаемости по третьим и последующим детям. В этой же работе приводятся результаты социологического опроса, проведенного в 2013 г. в Калужской и Новгородской областях и в Пермском крае. Согласно результатам этого опроса, у 55,6\% женщин введение регионального материнского капитала способствовало решению родить следующего ребенка; у $8,3 \%$ женщин введение регионального маткапитала привело к решению родить следующего ребенка раньше, чем они изначально предполагали.

В другом исследовании Владимир Архангельский и соавторы (2017) отмечают, что наибольший прирост суммарного коэффициента рождаемости 
по третьим и последующим рождениям за первую половину 2010-х гг. в России произошел именно в 2012 г., то есть сразу после введения большим количеством субъектов РФ региональных материнских капиталов. Рассматривая динамику рождаемости российских женщин в реальных когортах, Архангельский (2019) показывает, что увеличение вероятности рождения третьего ребенка в поколениях женщин, родившихся в конце 1970-х гг., по сравнению с предыдущими когортами может быть отчасти обусловлено активизацией мер по поддержке многодетных семей, в том числе и региональных материнских капиталов. Отметим однако, что не во всех регионах, которые указаны в данной статье как лидеры по росту рождаемости в реальных поколениях по третьим и последующим детям к началу 2018 г., на тот момент выплачивался региональный материнский капитал (этими регионами-лидерами являются Астраханская, Мурманская, Новгородская, Оренбургская и Свердловская области, в которых был зафиксирован наибольший рост доли женщин, родивших третьих детей, среди женщин, родивших вторых детей, в поколении 1970-х гг. по сравнению с поколением 1960-х гг.).

Таким образом, хотя введение региональных маткапиталов совпало с подъемом рождаемости третьих и последующих детей в РФ, исследований, которые позволяли бы утверждать, что эта мера стимулировала бы рождаемость на протяжении всего периода с начала ее действия, на данный момент нет. Также в перспективе всего времени действия этой меры остается неизученным вопрос о том, в какой степени размер и условия выплаты региональных маткапиталов объясняют межрегиональные различия по рождаемости третьих и последующих детей.

\section{Ежемесячные пособия многодетным семьям}

В приложении (таблица 2) приводятся основные данные по выплатам ежемесячных региональных пособий на третьего ребенка до достижения им трех лет в 2013, 2016 и 2019 гг. Число регионов, выплачивающих такие пособия, оставалось по годам довольно стабильным: в 2013 г. регионов, выплачивающих пособия, было 65, в 2016- 67, в 2019- 71. Распределение регионов по размерам пособия и условиям его выплат в основном также оставалось стабильным с 2013 по 2019 гг. В подавляющем большинстве регионов пособия весь этот период были равны региональному прожиточному минимуму на ребенка или незначительно отклонялись от него. Регионов, где размер пособия составлял менее $80 \%$ от этой суммы, за эти годы было менее десятка. Регионов, где размер пособия превышает уровень прожиточного минимума, также немного: ни в один из годов в исследуемом периоде их число не достигало десяти. В регионах, где проводятся выплаты пособий, среднее значение пособия достигало 11157 р. по состоянию на 2019 г., а медианное- 10289p.

Отличаются регионы и по условиям выплат пособий. Ни один регион не вводил эти пособия как предназначенные всем многодетным семьям, 
то есть данное пособие всегда рассматривается как мера поддержки только тех многодетных семей, которые имеют материальные трудности. Однако по конкретным условиям предоставления пособий регионы отличались. Как видно из таблицы 2, самый распространенный вариант- выплата пособия многодетным семьям, в которых доход на одного члена семьи меньше среднедушевого дохода по региону. На втором месте по распространенности- выплата только тем семьям, где доход на одного члена семьи ниже прожиточного минимума по региону. Отметим, что выбор между двумя этими вариантами не имеет жесткой связи с уровнем доходов населения в регионе: так, среди регионов, выплачивающих пособия только семьям с доходами ниже прожиточного минимума, есть и лидеры по доходам на душу населения (XМАО, ЯНАО), и регионы с низким уровнем доходов (Карелия). Другие варианты условий выплаты пособия представлены по регионам значительно меньше. Среди них-выплата пособия в случае, если среднедушевой доход в семье ниже полутора, двух или трех прожиточных минимумов или ниже определенной фиксированной суммы.

Среди регионов, не выплачивавших пособия на протяжении всего исследуемого периода, значительную долю составляют национальные республики, причем как те, где уровень рождаемости третьих и последующих детей заметно выше общероссийского (Дагестан, Чечня, Ингушетия, Тува), так и те, где этот уровень близок к общероссийскому (Адыгея, Кабардино-Балкария, Татарстан). Также не выплачивают пособий Красноярский край, Омская область (где пособие не выплачивается с 2013 г.) и Москва. Разнообразие уровней многодетности в регионах, не выплачивающих пособия, указывает на то, что для решений регионов, выплачивать пособие или нет, фактический уровень многодетности в регионе не является определяющим фактором.

Вопрос о влиянии ежемесячных пособий многодетным семьям на рождаемость не получил в литературе отдельного рассмотрения. Это может быть связано как с достаточно скромным масштабом этих мер, так и с тем, что они в основном вводились одновременно с региональными материнскими капиталами, и внимание исследователей концентрировалось на последних.

\section{Предоставление земельных участков}

В 2019 г. данная мера демографической политики применялась практически во всех регионах России, кроме Москвы, Ингушетии и Чечни. На протяжении 2010-х гг. число регионов, предоставляющих участки многодетным семьям, росло: в 2012 г. участки не предоставлялись в 12 регионах. Одними из последних к этой инициативе присоединились Ленинградская область, где предоставление участков началось только в 2019 г., и Брянская область, где оно началось двумя годами раньше. Участки можно использовать как под строительство, так и под личное подсобное хозяйство, в большинстве регионов размер участка составляет от 6 до 15 соток, в ряде 
случаев нижним пределом могут быть 3 сотки, а верхним 0,5 гектара. Размер предоставляемого участка также может быть разным в зависимости от выбранной семьей цели его использования (строительство индивидуального жилья, садоводство, животноводство). В ряде областей семьи, которые уже имеют земельные участки, получают право заменить данное натуральное пособие на денежную компенсацию.

Одновременно с ростом числа регионов, предоставляющих земельные участки многодетным семьям, все большее число регионов закрепляли право на бесплатный земельный участок только за какими-то отдельными категориями многодетных семей (чаще всего- за семьями, нуждающимися в улучшении жилищных условий). Так, в 2012 г. из 72 субъектов РФ, предоставлявших земельные участки многодетным семьям, 55 не устанавливали никаких специальных условий для предоставления участка; в 2015- из 79 регионов 49; в 2019 г.- из 83 регионов 40. Таким образом по мере распространения данной меры поддержки многодетных семей по регионам сокращается доля семей, которые могут ею реально воспользоваться.

В исследовании на основе результатов социологического опроса в трех регионах России, проведенном в 2013 г. (Архангельский, Джанаева 2014), делается вывод, что влияние этой региональной меры на репродуктивное поведение женщин было скромнее, чем влияние региональных маткапиталов. Тем не менее опрос показал, что для более трети (36\%) женщин возможность получить участок способствовала решению родить следующего ребенка, а у 17,9\% наличие такой возможности повлияло на решение родить ребенка раньше, чем первоначально планировалось. Позже подобных оценок не проводилось, и можно предположить, что сокращение категорий многодетных семей, имеющих право на бесплатный земельный участок, уменьшит эффект от этой меры для региональной рождаемости.

\section{Выводы}

Три ключевые региональные меры поддержки многодетных семей в РФ-выплаты региональных материнских капиталов, ежемесячные пособия многодетным семьям и предоставление им земельных участковвведены в большинстве регионов в начале 2010-х гг. по инициативе федерального правительства. Сегодня каждая из этих мер используется как минимум в трех четвертях субъектов РФ. Наиболее распространенная по регионам мера- выдача многодетным семьям земельных участков, на втором месте по распространенности- региональные материнские капиталы. Маткапиталы в большинстве регионов предоставляются семьям независимо от их материального положения, ежемесячные пособия- только семьям с доходами ниже определенного уровня, выдача земельных участков в значительном количестве регионов ограничена семьями, нуждающимися в улучшении жилищных условий. 
По размерам денежных выплат многодетным семьям регионы заметно отличаются друг от друга. При этом несмотря на изменчивость экономической ситуации на протяжении 2010-х гг, региональные меры поддержки многодетности в целом демонстрировали значительную стабильность, тенденции к сокращению этих мер не наблюдается. Вопрос об их эффективности, актуальный на фоне новых федеральных мер поддержки рождаемости, а также переживаемых страной экономических трудностей, изучен недостаточно и требует отдельного исследования.

\section{Выражение признательности}

Статья отражает исследования по НИР РАНХиГС 2020 г. «Рождаемость в регионах России: оценка роли выплат региональных материнских капиталов». Авторы благодарны Юлии Карпич за помощь в подготовке статьи.

\section{Список источников}

Андреев Е.М., Захаров С.В. (2017) Микроперепись-2015 ставит под сомнение результативность мер по поддержке рождаемости. Demoscope Weekly, 1-12 января. Доступно по ссылке: http://www.demoscope.ru/weekly/2017/0711/demoscope711.pdf (дата обращения: 26 марта 2020).

Архангельский В.Н. (2019) Рождаемость в реальных поколениях российских женщин: тенденции и региональные различия. Экономика. Налоги. Право, 12 (2): 59-69.

Архангельский В.Н., Джанаева Н.Г. (2014) Региональные особенности динамики рождаемости и демографическая политика. Уровень жизни населения регионов России, (1): 73-82.

Архангельский В.Н., Зинькина Ю. В., Коротаев А. В., Шульгин С. Г. (2017) Современные тенденции рождаемости в России и влияние мер государственной поддержки. Социологические исследования, (3): 43-50.

Елизаров В.В. (2014) Демографическое развитие России и ее регионов: общее и особенное. Уровень жизни населения регионов России, (1): 57-72.

Елизаров В.В. (2016) Экономическая поддержка семей с детьми в социально-демографической политике России: федеральные и региональные меры. А.И. Татаркин, А.И. Кузьмин (ред.) Динамика и инериионность воспроизводства населения и замещения поколений в России и СНГ. Т. 1. Екатеринбург: Институт экономики Уральского отделения РАН: $12-18$.

Исупова О.Г. (2018) Меры семейной политики в России в свете результатов микропереписи населения 2015 г. С. В. Захаров (ред.). Население России 2016: двадиать четвертый ежегодный демографический доклад. М.: Издательский дом НИУ ВШЭ: 260-301.

Казенин К.И, Ракша А.И. (2019) Динамика рождаемости по регионам РФ в 2018 г.: основные тенденции. Экономическое развитие России, 26 (8): 71-78.

Минтруд России (2019) Итоги года: поддержка семей с детьми и соииальное обслуживание населения. Доступно по ссылке: https://rosmintrud.ru/social/212 (дата обращения: 01 марта 2020 года).

Попова Л.А. (2016) Современная российская демографическая политика в области рождаемости: результаты и направления совершенствования. Экономические и социальные перемены: факты, тенденции, прогноз, 44 (2): 79-93. 
Выплаты региональных материнских капиталов в субъектах РФ в 2013, 2016, 2019 гг. ${ }^{1}$

\begin{tabular}{|c|c|c|c|}
\hline $\begin{array}{c}\text { Размер } \\
\text { материнского } \\
\text { капитала }\end{array}$ & 2013 & 2016 & 2019 \\
\hline Не выплачивается & $\begin{array}{l}\text { Архангельская } \\
\text { Астраханская } \\
\text { Москва } \\
\text { Краснодарский кр. } \\
\text { Ленинградская, } \\
\text { Пензенская } \\
\text { Башкортостан, } \\
\text { Татарстан } \\
\text { Ставропольский кр. } \\
\text { Чечня }\end{array}$ & $\begin{array}{l}\text { Москва } \\
\text { Пензенская } \\
\text { Пермский кр. } \\
\text { Татарстан } \\
\text { Ставропольский кр. } \\
\text { Чечня }\end{array}$ & $\begin{array}{l}\text { Астраханская } \\
\text { Московская } \\
\text { Новгородская } \\
\text { Омская } \\
\text { Пензенская } \\
\text { Пермский кр. } \\
\text { Северная Осетия } \\
\text { Татарстан } \\
\text { Смоленская } \\
\text { Ставропольский кр. } \\
\text { Чечня }\end{array}$ \\
\hline До 50 тыс. рублей & $\begin{array}{l}\text { Волгоградская } \\
\text { Вологодская } \\
\text { Курганская (2) } \\
\text { Нижегородская (2) } \\
\text { Приморский кр. } \\
\text { Дагестан (5) } \\
\text { Ингушетия (8) } \\
\text { Тюменская }\end{array}$ & $\begin{array}{l}\text { Курганская (2) } \\
\text { Нижегородская (2) } \\
\text { Дагестан (5) } \\
\text { Ингушетия (8) } \\
\text { Тюменская }\end{array}$ & $\begin{array}{l}\text { Курганская (2) } \\
\text { Дагестан (5) } \\
\text { Ингушетия (8) } \\
\text { Тюменская }\end{array}$ \\
\hline 50-100 тыс. рублей & $\begin{array}{l}\text { Курская } \\
\text { Липецкая } \\
\text { Адыгея } \\
\text { Алтай } \\
\text { Бурятия } \\
\text { Калмыкия } \\
\text { Марий Эл (4) } \\
\text { Северная Осетия } \\
\text { Тыва (5) } \\
\text { Рязанская } \\
\text { Тверская } \\
\text { Тульская } \\
\text { Челябинская } \\
\text { Ярославская }\end{array}$ & $\begin{array}{l}\text { Белгородская } \\
\text { Владимирская } \\
\text { Волгоградская } \\
\text { Забайкальский кр. } \\
\text { Ивановская } \\
\text { Калужская } \\
\text { Кировская } \\
\text { Курская } \\
\text { Липецкая } \\
\text { Адыгея } \\
\text { Алтай } \\
\text { Бурятия } \\
\text { Калмыкия } \\
\text { Марий Эл (4) } \\
\text { Северная Осетия } \\
\text { Тыва (5) } \\
\text { Рязанская } \\
\text { Тверская } \\
\text { Тульская } \\
\text { Челябинская } \\
\text { Ярославская }\end{array}$ & $\begin{array}{l}\text { Москва } \\
\text { Алтайский кр. } \\
\text { Архангельская } \\
\text { Белгородская } \\
\text { Владимирская } \\
\text { Волгоградская } \\
\text { Ивановская } \\
\text { Кировская } \\
\text { Курская } \\
\text { Адыгея } \\
\text { Алтай } \\
\text { Марий Эл (4) } \\
\text { Тыва (5) } \\
\text { Рязанская } \\
\text { Тверская } \\
\text { Тульская } \\
\text { Челябинская } \\
\text { Ярославская }\end{array}$ \\
\hline 100-150 тыс. рублей & $\begin{array}{l}\text { Ульяновская } \\
\text { Воронежская } \\
\text { ЕАО }\end{array}$ & $\begin{array}{l}\text { Ульяновская } \\
\text { Амурская } \\
\text { Брянская } \\
\text { Вологодская }\end{array}$ & $\begin{array}{l}\text { Бурятия (2) } \\
\text { Амурская (2) } \\
\text { Брянская } \\
\text { Вологодская }\end{array}$ \\
\hline
\end{tabular}

Продолжение на стр. 202

\footnotetext{
${ }^{1}$ Если региональный маткапитал выплачивается при рождении детей разных порядков, в таблице отражен маткапитал при рождении того ребенка, для которого сумма маткапитала наибольшая.
} 
100-150 тыс. рублей

Иркутская
Калининградская
Камчатский кр.
Карачаево-Черкессия (4),
Кемеровская
Красноярский кр.
Магаданская
Московская (2)
Мурманская
Новосибирская
Омская
Оренбургская
Орловская
Пермский кр.
Псковская
Карелия
Мордовия
Якутия
Хакасия
Ростовская
Самарская
Санкт-Петербург
Саратовская
Свердловская
Смоленская
Тамбовская
Томская
ХМАО
Чувашия
Чукотский АО

Воронежская

EAO (2)

Мурманская

4), Новосибирская

Омская

Оренбургская

Орловская

Псковская

Карелия

Мордовия

Якутия

Хакасия

Ростовская

Самарская

Санкт-Петербург

Саратовская

Свердловская

Тамбовская

Томская

XMAO

Чувашия

Чукотский $\mathrm{AO}$
Воронежская

EAO (2)

Забайкальский кр. (2)

Иркутская

Калининградская

Калужская

Камчатский край

Карачаево-Черкессия (4)

Кемеровская

Краснодарский кр.

Красноярский кр.

Ленинградская (2)

Липецкая

Магаданская

Мурманская

Нижегородская

Новосибирская

Ульяновская

Оренбургская

Орловская

Псковская

Бурятия

Калмыкия

Карелия

Мордовия

Якутия

Хакасия

Ростовская

Самарская

Саратовская

Свердловская

Тамбовская

Томская

XMAO

Чувашия

Чукотский $\mathrm{AO}$

\begin{tabular}{llll}
\hline 150 тыс. рублей и выше & Амурская & КБР (5) & Хабаровский кр. \\
& КБР (5) & Костромская & Приморский кр. \\
Костромская & Ненецкий АО & КБР (5) \\
Ненецкий АО & Новгородская & Камчатский кр. \\
Новгородская & Приморский кр. & Костромская \\
Коми & Башкортостан (8) & Ненецкий АО \\
Сахалинская & Коми & Башкортостан (8) \\
Удмуртия* & Сахалинская & Коми \\
Хабаровский кр. & Удмуртия* & Санкт-Петербург \\
ЯНАО & Смоленская & Сахалинская \\
& Хабаровский кр. & Удмуртия* \\
& ЯНАО & ЯНАО
\end{tabular}

*социальная выплата для погашения жилищного кредита 
Таблица 2

\section{Ежемесячные пособия многодетным семьям в регионах РФ}

в 2013, 2016, 2019 годах

\begin{tabular}{|c|c|c|c|c|}
\hline 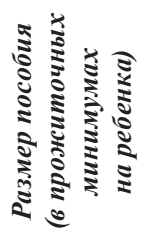 & 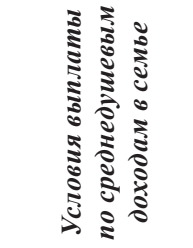 & 2013 & 2016 & 2019 \\
\hline $\begin{array}{l}\infty \\
0 \\
\sum \\
\sum \\
\sum\end{array}$ & $\begin{array}{l}\text { Ниже } \\
\text { прожиточного } \\
\text { минимума }\end{array}$ & $\begin{array}{l}\text { Амурская } \\
\text { Забайкальский кр. } \\
\text { Иркутская } \\
\text { НАО } \\
\text { Карелия } \\
\text { Якутия } \\
\text { Ростовская } \\
\text { Свердловская } \\
\text { Томская } \\
\text { ХМАО } \\
\text { Челябинская } \\
\text { ЯНАО }\end{array}$ & $\begin{array}{l}\text { Алтайский кр. } \\
\text { Амурская } \\
\text { Забайкальский кр. } \\
\text { Иркутская } \\
\text { Карачаево-Черкесия } \\
\text { Кемеровская } \\
\text { НАО } \\
\text { Карелия } \\
\text { Якутия } \\
\text { Свердловская } \\
\text { Томская } \\
\text { ХМАО } \\
\text { Челябинская } \\
\text { ЯНАО }\end{array}$ & $\begin{array}{l}\text { Алтайский кр. } \\
\text { Амурская } \\
\text { Астраханская } \\
\text { Забайкальский кр. } \\
\text { Иркутская } \\
\text { Карачаево-Черкессия } \\
\text { Кемеровская } \\
\text { Московская } \\
\text { НАО } \\
\text { Башкортостан } \\
\text { Карелия } \\
\text { Свердловская } \\
\text { Томская } \\
\text { ХМАО } \\
\text { Челябинская } \\
\text { ЯНАО }\end{array}$ \\
\hline $\begin{array}{l}I \\
\\
\\
\Sigma\end{array}$ & $\begin{array}{l}\text { Ниже полутора } \\
\text { прожиточных } \\
\text { минимумов }\end{array}$ & Санкт-Петербург & Санкт-Петербург & Санкт-Петербург \\
\hline 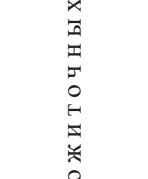 & $\begin{array}{l}\text { Ниже двух } \\
\text { прожиточных } \\
\text { минимумов }\end{array}$ & $\begin{array}{l}\text { Волгоградская } \\
\text { Вологодская } \\
\text { Воронежская }\end{array}$ & $\begin{array}{l}\text { Волгоградская } \\
\text { Вологодская } \\
\text { Воронежская }\end{array}$ & $\begin{array}{l}\text { Волгоградская } \\
\text { Вологодская } \\
\text { Воронежская } \\
\text { Пермский кр. } \\
\text { Калмыкия } \\
\text { Северная Осетия }\end{array}$ \\
\hline $\begin{array}{l}\stackrel{2}{1} \\
\text { n }\end{array}$ & $\begin{array}{l}\text { Ниже трех } \\
\text { прожиточных } \\
\text { минимумов }\end{array}$ & $\begin{array}{l}\text { Тульская } \\
\text { Калининградская }\end{array}$ & $\begin{array}{l}\text { Тульская } \\
\text { Калининградская }\end{array}$ & Тульская \\
\hline $\begin{array}{l}0 \\
\square \\
\infty \\
0 \\
0 \\
0\end{array}$ & $\begin{array}{l}\text { Ниже } \\
\text { среднедушевого } \\
\text { дохода }\end{array}$ & $\begin{array}{l}\text { Архангельская } \\
\text { Белгородская } \\
\text { Брянская } \\
\text { Владимирская } \\
\text { ЕАО } \\
\text { Ивановская } \\
\text { Калужская } \\
\text { Камчатский кр. } \\
\text { Костромская } \\
\text { Краснодарский кр. } \\
\text { Курганская } \\
\text { Курская** } \\
\text { Ленинградская } \\
\text { Липецкая } \\
\text { Мурманская } \\
\text { Нижегородская } \\
\text { Новгородская } \\
\text { Новосибирская } \\
\text { Омская }\end{array}$ & $\begin{array}{l}\text { Архангельская } \\
\text { Белгородская } \\
\text { Брянская } \\
\text { Владимирская } \\
\text { ЕАО } \\
\text { Ивановская } \\
\text { Калужская } \\
\text { Камчатский край } \\
\text { Костромская } \\
\text { Краснодарский кр. } \\
\text { Курганская } \\
\text { Курская** } \\
\text { Ленинградская } \\
\text { Липецкая } \\
\text { Мурманская } \\
\text { Нижегородская } \\
\text { Новгородская } \\
\text { Новосибирская } \\
\text { Орловская }\end{array}$ & $\begin{array}{l}\text { Архангельская } \\
\text { Белгородская } \\
\text { Брянская } \\
\text { Владимирская } \\
\text { ЕАО } \\
\text { Ивановская } \\
\text { Калужская } \\
\text { Камчатский край } \\
\text { Костромская } \\
\text { Курганская } \\
\text { Курская** } \\
\text { Липецкая } \\
\text { Мурманская } \\
\text { Нижегородская } \\
\text { Новгородская } \\
\text { Новосибирская } \\
\text { Орловская } \\
\text { Приморский край } \\
\text { Псковская }\end{array}$ \\
\hline
\end{tabular}

Продолжение на стр. 204 


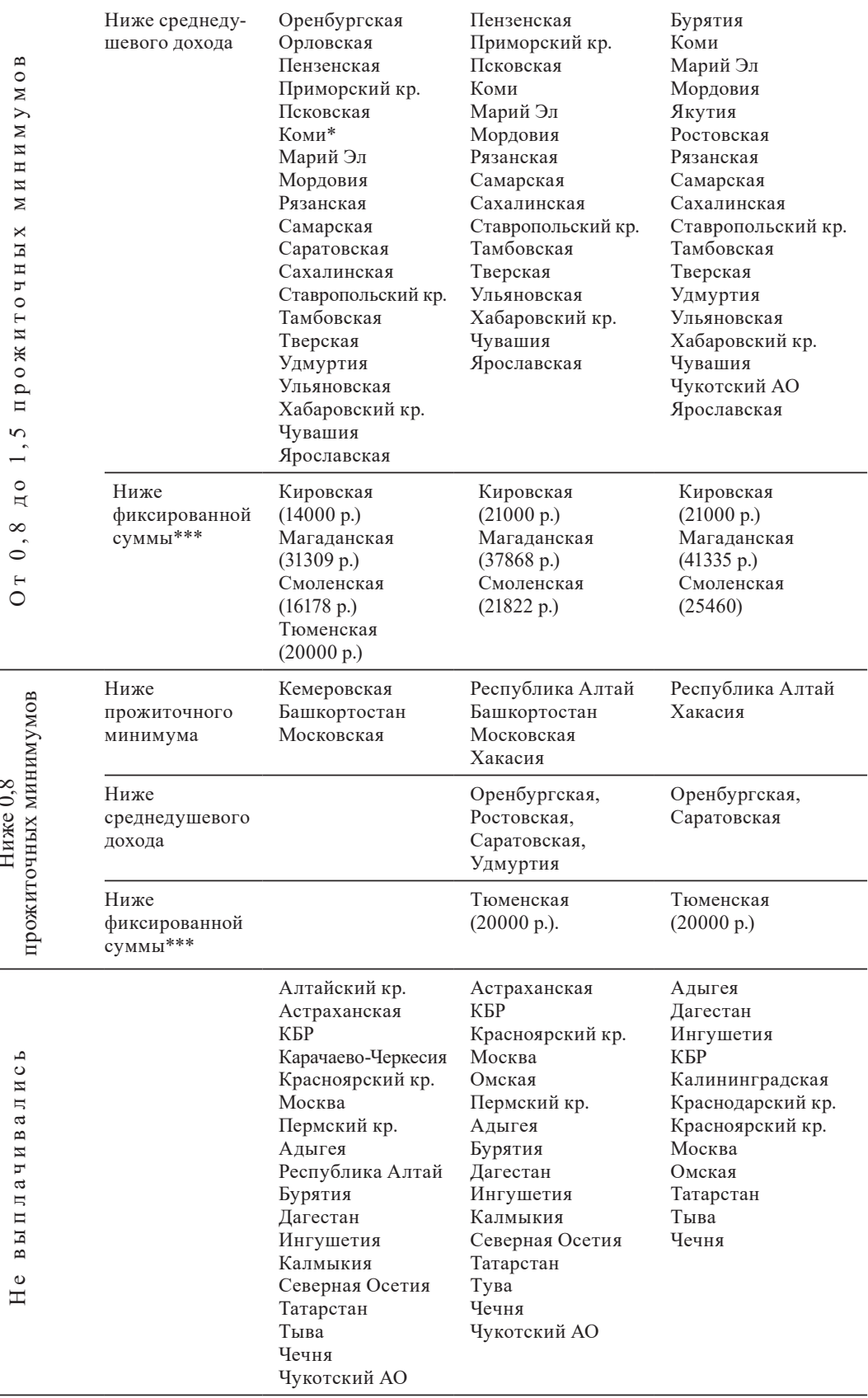

\footnotetext{
*1,72 прожиточных минимума

** семьям с доходом выше среднедушевого про региону на члена семьи- 3000 p

*** сумма устанавливается региональным законом
} 
Konstantin Kazenin, Vladimir Kozlov

\section{REGIONAL MEASURES OF SUPPORT FOR FAMILIES WITH THREE AND MORE CHILDREN: AN OVERVIEW}

The paper reviews regional pronatalist measures recently established in Russia. Although much attention is paid by researchers to pronatalist measures introduced by the Russian federal government, regional measures of this kind are neither studied in the aspect of their efficiency nor properly systematized. Most of Russia's regions introduced special measures of support for families having children in the early 2010 s on the incentive of the federal government. Most of these measures are addressed to families having three or more children. In many regions non-recurrent allowances ('maternity capitals') are offered to families at the birth of the third child. Besides, many regions supply families with monthly allowances after the birth of the third child and provide them with allotments of free land. Overall, at least three quarters of Russia's regions use each of these measures. The review deals with every regional pronatalist measure separately. Regions differ in amounts of money paid as non-recurrent and monthly allowances and in conditions under which these allowances and land allotments are available to families with three or more children. These differences between regions are considered for all the period from introduction of the regional pronatalist measures in the overview. It is shown that despite the economic volatility of the 2010 s, the system of regional pronatalist measures was gradually expanding in that period. Cuts of some of these measures by regions were rare. Existing studies on the relationship between regional pronatalist measures and fertility are scrutinised. It is argued that further study of these measures is needed in order to assess their efficiency.

Key words: fertility, regions, maternity capital, families with three or more children

DOI: 10.17323/727-0634-2020-18-2-191-206

\section{References}

Andreev E. M., Zakharov S. V. (2017) Mikroperepis'-2015 stavit pod somnenie rezul'tativnost' mer po podderzhke rozhdaemosti [Microcensus-2015 Casts Doubts on Efficiency of Pronatalist Measures]. Demoscope Weekly, 1-12 January. Available at: http://www. demoscope.ru/weekly/2017/0711/demoscope711.pdf (accessed 26 March 2020).

Konstantin I. Kazenin - PhD (Kandidat Nauk) in Philology, director of the Center for Regional Studies and Urbanistics, Russian Academy for National Economy and Public Administration, Moscow, Russian Federation. Email: kz@ranepa.ru

Vladimir A. Kozlov- PhD (Kandidat Nauk) in Economics, associate professor, Institute for Demography, National Research Institute 'Higher School of Economics', Moscow, Russian Federation. Email: vakozlov@hse.ru 
Arkhangel'ski V.N. (2019) Rozhdaemost' v real'nykh pokolenijakh rossijskikh zhen'shchin: tendencii i regional'nye razlichija [Fertility in Real Cohorts of Russian Women: Tendencies and Regional Differences]. Ekonomika, nalogi, parvo [Economics, Taxes, Law], 12 (2):59-69.

Arkhangel'ski V.N., Dzhanaeva N. G. (2014) Regional'nye osobennosti dinamiki rozhdaemosti i demograficheskaja politika [Regional Characteristics of Fertility Dynamics and Demographic Policy]. Uroven' zhizni naselenija regionov Rossii [Level of Life of Population of Russian Regions], (1): 73-82.

Arkhangel'ski V.N., Zin'kina Ju.V., Korotaev A. V., Shul'gin S.G. (2017) Sovremennye tendencii rozhdaemosti v Rossii i vlijanie gosudarstvennykh mer podderzhki [Today's Fertility Tendencies in Russia and the Effect of State Support Measures]. Sociologicheskie issledovanija [Sociological studies], (3): 43-50.

Elizarov V.V. (2014) Demograficheskoe razvitie Rossii i ee regionov: obshchee i osobennoe [Demographic Development of Russian Regions: General and Specific]. Uroven' zhizni naselenija regionov Rossii [Level of Life of Population of Russian Regions], (1): 57-72.

Elizarov V.V. (2016) Ekonomicheskaja podderzhka semej s det'mi v social'no-demograficheskoj politike Rossii: federal'nye i regional'nye mery [Economic Support of Families with Children in Socio-Demographic Policy of Russia: Federal and Regional Measures]. A. I. Tatarkin, A. I. Kuz'min (ed.) Dinamika i inercionnost» vosproizvodstva naselenija $i$ zameshchenija pokolenij $v$ Rossii $i$ SNG [Dynamics and Stability of Population Reproduction and Substitution of Generations in Russia and CIS]. V.1. Ekaterinburg: Institut Ekonomiki Ural'skogo Otdeleniya RAN: 12-18.

Isupova O. G. (2018) Mery semejnoj politiki v Rossii v svete rezul'tatov mikroperepisi naselenija 2015 g. [Family Policy Measures in Russia and Results of Microcensus-2015]. In: S. V. Zakharov (ed.). Naselenie Rossii 2016: dvadcat» chetvjortyj ezhegodnyj demograficheskij doklad [Population of Russia 2016: the 24 ${ }^{\text {th }}$ Annual Demographic Report]. Moscow: Izdatel'skij dom NIU VShE: 260-301.

Kazenin K. I., Raksha A. I. (2019) Dinamika rozhdaemosti po regionam RF v 2018 g.: osnovnye tendencii [Fertility Dynamics in Regions of Russia in 2018: Key Tendencies]. Ekonomicheskoe razvitie Rossii [Economic Development of Russia], 26 (8): 7-78.

Mintrud Rossii (2019) Itogi goda: podderzhka semej s det'mi i social'noe obsluzhivanie naselenija [Results of the Year: Support of Families with Children and Social Services for Population]. Available at: https://rosmintrud.ru/social/212 (accessed 01 March 2020).

Popova L.A. (2016) Sovremennaja rossijskaja demograficheskaja politika v oblasti rozhdaemosti: rezul'taty i napravlenija sovershenstvovanija [Today's Russian Demographic Policy in the Sphere of Fertility: Results and Ways of Imporovement]. Ekonomicheskie $i$ social'nye peremeny: fakty, tendencii, prognoz [Economic and Social Changes: Facts, Tendencies, Forecasting], 44 (2): 79-93. 